\title{
SYNTHESES AND STRUCTURE DETERMINATIONS OF SOME SELENOCYANATO- AND THIOCYANATO-KOJIC ACID DERIVATIVES.
}

\author{
L. RONDAHL \\ Institute of Chemistry, Västergårdgymnasiet, Södertälje, Sweden \\ M. UHER \\ Department of Organic Chemistry, Faculty of Chemical and Food Technology, Slovak Technical University, Bratislava, \\ Slovak Republic \\ J. BRTKO* \\ Institute of Experimental Endocrinology, Slovak Academy of Sciences, Bratislava, Slovak Republic
}

\begin{abstract}
Kojic acid (5-hydroxy-2-hydroxymethyl-4-pyranone) and analogues have been reported as biologically active compounds. Four kojic acid thiocyanato- and selenocyanatoanalogues have been prepared in order to investigate them for antineoplastic effects
\end{abstract}

Background: Kojic acid (5-hydroxy-2-hydroxymethyl-4-pyranone) and analogues have been reported as biologically active compounds. Most of these compounds have been tested for effects on selected biological processes in a variety of in vitro test systems ${ }^{1,2}$. Some of the kojic acid derivatives have been shown to exert antineoplastic effects in vivo ${ }^{3.4}$. Among the kojic acid derivatives there are some sulphur-containing compounds, e.g. 5-benzyloxy-2-thiocyanatomethyl4-pyranone (1) that have been shown to significantly inhibit neoplastic cell growth as well as DNA and RNA synthesis ${ }^{5}$. There has since many years been a debate about anticarcinogenic effects of selenium and selenium compounds in nutritionally acceptable low doses. This debate has stimulated the search for anticancer selenium agents and drugs with low toxicity. The majority of organic selenium compounds investigated for antineoplastic activity have been selenium analogues of sulphur compounds. Benzyl thiocyanate and benzyl selenocyanate have been investigated for antitumour activity. The benzyl selenocyanate, administered in the diet, has been shown to inhibit intestinal carcinogenesis in rats and mice while the benzylthiocyanate was inactive at the same doses ${ }^{6}$. Due to these results we found it interesting to synthesize some kojic acid derivatives of thio- and selenocyanates for testing of antineoplastic activity

Results: We have prepared four analogues (Fig 1) in order to investigate them for antineoplastic effects. The preparation method for the substances has been in three steps according to Uher et al ${ }^{7}$ with some modifications; benzylation or methylation of kojic acid, chlorination with thionyl chloride, nucleophilic substitution with thio- or selenocyanate.<smiles>[R]Oc1coc(CC#N)cc1=O</smiles><smiles>[R]Oc1coc(CC#N)cc1=O</smiles><smiles>Cc1ccccc1</smiles>

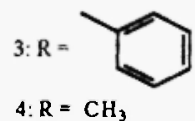

Fig. 1: Structures of kojic acid derivatives 


\section{Experimental:}

5-Benzyloxy-2-selenocyanatomethyl-4-pyranone. A solution of $1.7 \mathrm{~g}(0.012 \mathrm{~mol})$ potassium selenocyanate in $10 \mathrm{ml}$ acetone was added to a suspension of $2.5 \mathrm{~g}(0.010 \mathrm{~mol})$ 5-benzyloxy-2-chloromethyl-4-pyranone ${ }^{4}$ in $50 \mathrm{ml}$ acetone. During reflux for $1 \mathrm{~h}$ a precipitation of potassium chloride was observed. After addition of approximately $100 \mathrm{ml}$ of distilled water the resulting mixture was filtered and the precipitate was washed with water. Recrystallization from ethanol gives a pure sample in $88 \%$ yield, mp 128-130 ${ }^{\circ} \mathrm{C} .{ }^{1} \mathrm{H}$ NMR (DMSO- $\left.\mathrm{d}_{6}\right): 8.26(\mathrm{~s}, 1 \mathrm{H}, \mathrm{H6}), 7.40\left(\mathrm{~s}, 5 \mathrm{H}, \mathrm{H}_{\text {arom }}\right.$ ), $6.40(\mathrm{~s}, 1 \mathrm{H}, \mathrm{H} 3), 4.95\left(\mathrm{~s}, 2 \mathrm{H}, \mathrm{Ph}-\mathrm{CH}_{2}\right), 4.17\left(\mathrm{~s}, 2 \mathrm{H}, \mathrm{CH}_{2}-\mathrm{Se}\right)$. Mass spectrum, $\mathrm{m} / \mathrm{z}\left(\mathrm{I}_{\mathrm{r}} / \%\right) ; 321$ (2) (M+-); $215(80) ; 91$ $(100) ; 65(18)^{8}$

5-Methoxy-2-selenocyanatomethyl-4-pyranone. A solution of $0.21 \mathrm{~g}(1.2 \mathrm{mmol})$ potassium selenocyanate in $2 \mathrm{ml}$ acetone was added to a suspension of $0.20 \mathrm{~g}(1.4 \mathrm{mmol}) 5$-methoxy-2-chloromethyl-4-pyranone [8] in $10 \mathrm{ml}$ acetone. The solution was filtered and evaporated. The residue was crystallized and recrystallized from ethanol to give a pure sample in $75 \%$ yield, mp $128-131{ }^{\circ} \mathrm{C} .{ }^{1} \mathrm{H}$ NMR (DMSO-d $\mathrm{d}_{6}$ ): $8.16(\mathrm{~s}, 1 \mathrm{H}, \mathrm{H} 6), 6.36(\mathrm{~s}, 1 \mathrm{H}, \mathrm{H} 3), 4.16\left(\mathrm{~s}, 2 \mathrm{H}, \mathrm{CH}_{2}-\mathrm{Se}\right.$ ), $3.67\left(\mathrm{~s}, 3 \mathrm{H}, \mathrm{CH}_{3}\right)$. Mass spectrum, m/z (I/\%): $245(78)(\mathrm{M}+\cdot) ; 139(100) ; 215(36)^{8}$.

5-Benzyloxy-2-thiocyanatomethyl-4-pyranone was prepared according to Uher et al. 1995 , mp $128-130^{\circ} \mathrm{C}^{5,9}$. Mass spectrum, $\mathrm{m} / \mathrm{z}$ (I/\%): 273 (20) (M+•); 215 (40); 91 (100); 65 (86).

5-Methoxy-2-thiocyanatomethyl-4-pyranone. A solution of $0.87 \mathrm{~g}(5.0 \mathrm{mmol})$ potassium thiocyanate in $5 \mathrm{ml}$ acetone was added to a suspension of $0.6 \mathrm{~g}(6.0 \mathrm{mmol}) 5$-methoxy-2-chloromethyl-4-pyranone ${ }^{8}$ in $20 \mathrm{ml}$ acetone. After reflux for $1 \mathrm{~h}$ the mixture was filtered and the filtrate evaporated. The residue was crystallized and recrystallized from toluene to give a pure sample in $50 \%$ yield, mp 119-126 ${ }^{\circ} \mathrm{C}$. ${ }^{1} \mathrm{H}$ NMR (DMSO-d $)$ ): 8.20 (s, 1H, H6), $6.44(\mathrm{~s}, 1 \mathrm{H}, \mathrm{H} 3), 4.32$ (s, $2 \mathrm{H}, \mathrm{CH}_{2}-\mathrm{S}$ ), 3.67 (s, 3H, $\mathrm{CH}_{3}$ ). Mass spectrum, m/z (Ir\%): 197 (24) (M+*); 167 (12); 139 (100).

The elemental analyses $(\mathrm{C}, \mathrm{H}, \mathrm{N})$ gave acceptable results for all syntheses.

Acknowledgement: This work has been supported by the Centre of Excellence grant No. ICA1-CT-2000-70008 and in part by the VEGA grant 2/2070/22.

\section{References:}

1. D. Hudecova, M.Uher and J. Brtko, Biologia 47, 483 (1992)

2. S. Baláz, E. Sturdik, R. Ujhelyiová, D. Valigura, M. Uher, M. Veverka, V. Konecny, J. Adamcova, P. Michalik and J. Brtko, Collect. Czech. Chem. Commun. 58, 693 (1993)

3. J. Bransova, J. Brtko, M. Uher and L. Novotny, Int. J. Biochem. Cell Biol. 27, 701 (1995)

4 J. Bransova, M. Uher and J. Brtko, Anticancer Res. 18, 4423 (1998)

5. J. Bransova, M. Uher, L. Novotny, and J. Brtko, Anticancer Res. 17, 1175 (1997)

6. M.J. Parnham and E. Graf, Pharmacology of synthetic organic selenium compounds. Progress in Drug Research, vol. 36. Birkhäuser Verlag Basel (1991)

7. M. Uher, J. Bransova, O. Rajniaková, D. Hudecova and J. Brtko, Patent No.: 281408 (2000)

8 J. Brko, L. Rondahl, D. Hudecova, M. Fickova and M. Uher, Patent pending (2002)

9. M. Uher, J. Bransova, J Brtko, D Hudecova, J. Dobias and P. Filipcik, Patent No.: 278075 (1995)

\section{Received on February 5, 2003}

